\title{
Women's interest in birth centre care - is it time to make more options available?
}

\section{Opieka okołoporodowa w domach narodzin w opinii kobiet. Czy nadszedt czas na wprowadzenie nowych możliwości?}

\author{
Julia Nawrot ${ }^{1}$, Agnieszka Gniadek², Aneta Suder ${ }^{3}$ \\ 1Department of Rudiments of Midwifery, Institute of Nursing and Midwifery, Faculty of Health Sciences, Jagiellonian University Medical \\ College, Krakow, Poland \\ Head of the Department: Barbara Prażmowska PhD \\ ${ }^{2}$ Department of Nursing Management and Epidemiological Nursing, Faculty of Health Sciences, Jagiellonian University Medical College, \\ Krakow, Poland \\ Head of the Department: Prof. Agnieszka Gniadek \\ 'Department of Neonatology, University Hospital, Krakow, Poland \\ Head of the Department: Prof. Ryszard Lauterbach MD, PhD
}

Key words: midwife, natural childbirth, Birthing Centers.

Słowa kluczowe: położna, poród naturalny, domy narodzin.

\begin{abstract}
Introduction: Birth centers, otherwise known as midwife-led units, midwifery units, are designed for women in physiological pregnancy, who would like to give birth in a possibly natural way. This type of care offers homelike environment, with basic medical equipment on-site.

Aim of the research: To explore women's preferences regarding an alternative model of perinatal care in birth centers. Material and methods: A two-phase study was used. In this exploratory descriptive study quantitative data were collected by anonymous questionnaire from 153 women in Poland from January 2017 to May 2017. A sample of women of childbearing age from various parts of Poland were recruited via the Internet and in-person.

Results: Almost 79\% of respondents declared their interest in giving birth in a natural rhythm led by a midwife. From the group potentially interested in giving birth in a birthing centre $41.2 \%$ of respondents fully agreed with the statement "Physiological birth in the home is a safe alternative to giving birth in the hospital", and $23.5 \%$ of the respondents from the same group agreed with the above statement partially. All aspects that are the domains of midwife-led care in birth centres, such as the use of non-pharmacological pain relief, one-to-one midwife care during delivery, and intimate homelike surroundings, were important for over $70 \%$ of respondents.

Conclusions: Women show interest in birth centre care during the perinatal period. Introducing birth centres into perinatal care for women in a physiological pregnancy with low risk of complications may match their needs.
\end{abstract}

\section{Streszczenie}

Wprowadzenie: Domy narodzin, inaczej nazywane oddziałami prowadzonymi przez położne, są placówkami przeznaczonymi dla kobiet w fizjologicznej ciąży, które chciałyby urodzić w możliwie niezakłócony sposób, w warunkach zbliżonych do warunków domowych i jednocześnie zapewniających zaplecze medyczne.

Cel pracy: Przedstawienie informacji na temat preferencji kobiet dotyczących alternatywnej formy opieki okołoporodowej, jaką jest opieka prowadzona przez położne w domach narodzin, a także poznanie opinii na jej temat i sposobu jej postrzegania przez kobiety.

Materiał i metody: Przeprowadzono badanie dwuetapowe, opisowe. Dane ilościowe zebrano z wykorzystaniem autorskiego kwestionariusza ankiety w grupie 153 kobiet w Polsce od stycznia do maja 2017 roku. Grupę badaną stanowiły kobiety w wieku rozrodczym z różnych części Polski, rekrutowane za pośrednictwem Internetu lub tradycyjnie.

Wyniki: Prawie 79\% respondentek zadeklarowało zainteresowanie porodem w naturalnym rytmie prowadzonym przez położną w domu narodzin. Z grupy potencjalnie zainteresowanej porodem $\mathrm{w}$ domu narodzin $41,2 \%$ respondentek całkowicie zgodziło się ze stwierdzeniem: „Fizjologiczne porody w domu to bezpieczna alternatywa dla porodu w szpitalu”, a 23,5\% zgodziło się z powyższym stwierdzeniem częściowo. Zagadnienia charakterystyczne dla opieki w domach narodzin, takie jak stosowanie niefarmakologicznego leczenia bólu, opieka jeden na jeden podczas porodu, intymne i przytulne otoczenie, były ważne dla ponad 70\% respondentek.

Wnioski: Wprowadzenie domów narodzin do systemu opieki okołoporodowej dla kobiet w ciąży fizjologicznej o niskim ryzyku wystąpienia powikłań może odpowiadać ich potrzebom. 


\section{Introduction}

Every year there are about 140 million births in the world, most of which are uncomplicated. However, there has been a substantial increase over the last two decades in women being subjected to medical interventions in the name of risk-avoidance, which may be unnecessary [1]. Birth centres, also referred as midwifery units or birthing units, are dedicated to healthy women in normal pregnancies, who want to give birth in a uninterrupted way in a homelike but also well-equipped facility. This model of care belongs to the "midwife-led model of care". It has been the aim of several research also in terms of the possibility of reducing the 1980s-style medicalisation during pregnancy and delivery. Some birth centres are separate from a hospital (freestanding midwifery unit), but many hospitals have midwife-led birth centres alongside their conventional, consultant-led, maternity units (alongside a midwifery unit). Deliveries in birth centres are a minority in most countries in the world where this model is available. The exceptions, in which the percentage of births outside the hospital is slightly higher are Australia, New Zealand, and the United Kingdom [2, 3]. The United Kingdom has an extensive network of hospitals and free-standing birth centres. The first birth centre in Poland was a private, freestanding birth centre, which operated in Warsaw during 2006-2008. Currently functioning in Poland are a hospital-based birth centre at St. Zofia in Warsaw and a freestanding birth centre in Łomianki [4, 5].

Number of medical procedures during the normal birth in a birth centre is limited. Midwives do not routinely perform episiotomies or enemas. Intravenous approach is made only in cases with clear indications. Medical staff and midwives do not intervene to speed up a woman's labour unless there are real risks of complications. Pharmacology or any other invasive methods are not used to induce or stimulate labour. Foetal well-being monitoring is carried out with a one-time cardiotocography (CTG), and then CTG is repeated only if necessary. Foetal heart rate during the first and second stage of labour is monitored with a portable heart rate detector according to applicable guidelines. In the case of indications for permanent heart rate monitoring the midwife conducts and interprets the CTG record. Only non-pharmacological methods are used. It is not possible to use epidural anaesthesia because it requires the presence of an anaesthesiologist and intensified medical care, which includes intravenous fluid therapy and continuous cardiotocography monitoring. This type of anaesthesia requires transfer to the hospital ward, which is possible at the request of the woman. However, women may often use gas and air for labour (oxygen and nitrous oxide gas). In some facilities, intravenous anaesthesia like pethidine injections is also used [2, 3]. Women usually have at their disposal water immersion, very often as a bath or birth pool, massage and reflexology, aromatherapy and music therapy, application of heat and cold, and sometimes transcutaneus electrical nerve stimulation (TENS) or acupuncture [2, 3]. Midwives encourage women to choose the best position for themselves in the first and second stage of labour, and encourage verbalisation of pain sensations. Support during childbirth also involves listening to the woman's needs and using her own resources to cope with pain $[2,6]$. There are no restrictions on eating and drinking or movement. In the case of a physiological early puerperium, the time of observation of the mother and newborn baby varies from $6 \mathrm{~h}$ to 1-2 days [2].

There are several practices for healthy, safe labour in a birth centre. One of the most important is a rigorous procedure of qualification, admission, and transfer. Qualification is usually carried out for the first time at 37 weeks of gestation by a gynaecologist and midwife, and then once again at admission. A woman who would like to give birth in a birth centre must be healthy and have a low-risk pregnancy [6]. In the case of emergencies during labour or puerperium, when medical intervention or access to the operating room is necessary, the woman is transferred to a consultantled unit. The distance between the birth centre and hospital is often regulated. Regulations specify the maximum distance between one facility and the other, ensuring a sufficiently short time of ambulance or hospital ambulance. Midwives also provide all necessary medical documentation $[2,5]$.

\section{Aim of the research}

The aim of this study was to ascertain women's opinions and perceptions about birth centre care led by midwives.

\section{Material and methods}

\section{Study design}

A two-phase mixed methodology study was used. In this exploratory descriptive study quantitative data were collected by anonymous questionnaire from 153 women in Poland. The proper study, which was presented in the paper, was preceded by a pilot study on a group of 30 women. After analysis of the answers, the construction of a few questions from the first version of the questionnaire was corrected. Interviews took place from January 2017 to May 2017 on a targeted sample of women of childbearing age from various parts of Poland via the Internet and traditionally. The inclusion criteria were: 18 to 49 years old, consent to participate in the study, and the ability to use the Polish language to the extent that the questionnaire could be completed. No other criteria were applied because participants with a wide variety of characteristics were intentionally sought. All respondents received clear, written information about the nature and 
purpose of the survey. The 23-item self-administered questionnaire asked about women's knowledge or lack of awareness of the midwife-led model of care and the most important characteristics. They also included questions on personal demographic data and the women's obstetric history. The questionnaires also included specific statements about women's perceptions of childbirth as a life-event, the actual model of care in Poland, and care in birth centres during the intrapartum and postpartum periods, with response alternatives ranging from "agree completely" $(=1)$ to "do not agree at all” (=5). Questions about important aspects of perinatal care were multiple choice questions.

\section{Data collection and analysis}

Data analysis consisted of descriptive statistics of categorical variable distribution, which were presented as counts and percentages. The $\chi^{2}$ test or Fisher's exact test (in the case when the expected cell counts were small) was used to examine relationships between categorical variables. A significance level of $\alpha=0.05$ was assumed. Statistica 12.0 and the Office Excel program were used for analysis.

\section{Results}

We collected 153 completed questionnaires. Participants ranged in age from 21 to 49 years. More than $61 \%(n=94)$ were pregnant at least once. Table 1 presents the sociodemographic data of the respondents.

Familiarity with the model of care in birth centres was declared by $44 \%(n=67)$ of respondents. Almost $79 \%$ of respondents declared their interest in giving birth in a natural rhythm led by a midwife. The most frequently mentioned aspects associated with care in birth centres by respondents were: "support for a physiological birth process" $(80 \%, n=123)$, "conscious participation in childbirth" $(75 \%, n=114)$, "giving birth in any preferred position" (72\%, $n=110)$, "natural childbirth" (70\%, $n=107)$, and a "home-like surrounding" (69\%, $n=106)$. The fewest respondents indicated the following responses: "high cost of delivery, no refund" $(22 \%, n=34)$ and "home birth with midwife-led care" $(24 \%, n=37)$. The results are presented in Figure 1 .

\section{Information on the midwife-led model of care}

Women's views on the care provided in hospital wards and birth centres are presented in Table 2 in the form of a percentage indicator for each question. Most women $(84.3 \%, n=129)$ fully or partially agreed with the statement: "An increased level of medicalisation of childbirth can be observed in the labour wards in Poland". Only 2.6\% of respondents disagreed with this statement $(n=4)$. For over $91 \%(n=140)$ of women it was important to give birth without unnecessary medical intervention. Women agreed with the statement "Midwives are prepared to provide care in
Table 1. Sociodemographic characteristics of participants

\begin{tabular}{|lccc|}
\hline Parameter & & $\mathbf{N}$ & $\%$ \\
Age [year] & $20-32$ & 84 & 54.9 \\
\cline { 2 - 4 } Parity & $33-49$ & 69 & 45.1 \\
& Nulligravida & 59 & 38.6 \\
\cline { 2 - 4 } & Primagravida & 27 & 17.6 \\
\cline { 2 - 4 } Education & Gravid 2 & 36 & 23.5 \\
\cline { 2 - 4 } & Gravid $\geq 3$ & 31 & 20.2 \\
\cline { 2 - 4 } Martial status & High school & 25 & 16.3 \\
\cline { 2 - 4 } & University & 128 & 83.7 \\
\cline { 2 - 4 } Place of living & Single & 16 & 10.5 \\
\cline { 2 - 4 } & Married/cohabiting & 137 & 89.5 \\
\cline { 2 - 4 } & Country & 47 & 37.7 \\
\hline
\end{tabular}

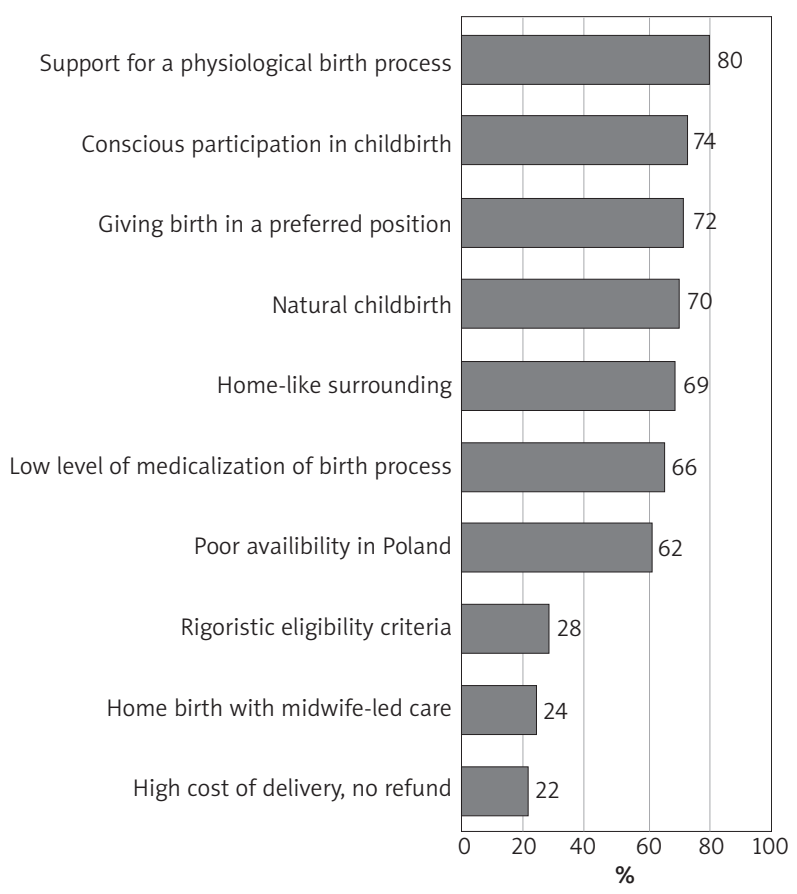

Figure 1. Characteristics of care in birth centres mentioned by respondents (more than one answer could be given to the question)

birth centres" in $78.5 \%(n=110)$. With the statement that "Every labour outside the hospital ward is risky and it should always take place in a hospital", $12.4 \%$ of respondents $(n=19)$ agree completely, $37.3 \%$ of respondents $(n=57)$ partially agree with this statement. $37.2 \%$ of respondents $(n=57)$ disagree with it (partly or completely), while $13.1 \%(n=20)$ of respondents have no opinion on this topic. In the study group $42.5 \%$ of women $(n=65)$ fully agree with the state- 
Table 2. Characteristics of the variability of responses to questions (How far you agree with this statement?) about opinion on perinatal care - comparison

\begin{tabular}{|c|c|c|c|c|c|}
\hline Variable & $\begin{array}{l}\text { I totally } \\
\text { agree } \\
(\%)\end{array}$ & $\begin{array}{l}\text { I partly } \\
\text { agree } \\
\text { (\%) }\end{array}$ & $\begin{array}{l}\text { I have } \\
\text { no opinion } \\
\text { (\%) }\end{array}$ & $\begin{array}{l}\text { I do not } \\
\text { agree } \\
\text { (\%) }\end{array}$ & $\begin{array}{l}\text { I totally } \\
\text { disagree } \\
\text { (\%) }\end{array}$ \\
\hline $\begin{array}{l}\text { It is necessary to introduce birth centers to health care } \\
\text { system as a model of care led by midwives for women } \\
\text { in physiological pregnancy }\end{array}$ & 58.2 & 30.1 & 11.8 & 0 & 0 \\
\hline $\begin{array}{l}\text { An increased level of medicalization of childbirth can } \\
\text { be observed in the labour wards in Poland }\end{array}$ & 41.8 & 42.5 & 13.1 & 2.6 & 0 \\
\hline $\begin{array}{l}\text { It is important for me to give birth without unnecessary } \\
\text { medical intervention }\end{array}$ & 68 & 23.5 & 3.3 & 5.2 & 0 \\
\hline $\begin{array}{l}\text { I would like to give birth in a home-like atmosphere with } \\
\text { specialists, attentive care in labour and birth }\end{array}$ & 69.3 & 14.4 & 10.5 & 5.9 & 0 \\
\hline Midwives are prepared to provide care in birth centers & 39.9 & 38.6 & 13.1 & 7.2 & 1.3 \\
\hline $\begin{array}{l}\text { Normal birth of a healthy woman and a healthy child is } \\
\text { a physiological life event }\end{array}$ & 42.5 & 45.1 & 5.2 & 5.9 & 1.3 \\
\hline $\begin{array}{l}\text { Every labour outside the hospital ward is risky } \\
\text { and it should always take place in a hospital }\end{array}$ & 12.4 & 37.3 & 13.1 & 23.5 & 13.7 \\
\hline $\begin{array}{l}\text { Giving birth in a birth center is a safe alternative for } \\
\text { giving birth in a hospital ward }\end{array}$ & 42.5 & 37.9 & 14.4 & 4.6 & 0.7 \\
\hline
\end{tabular}

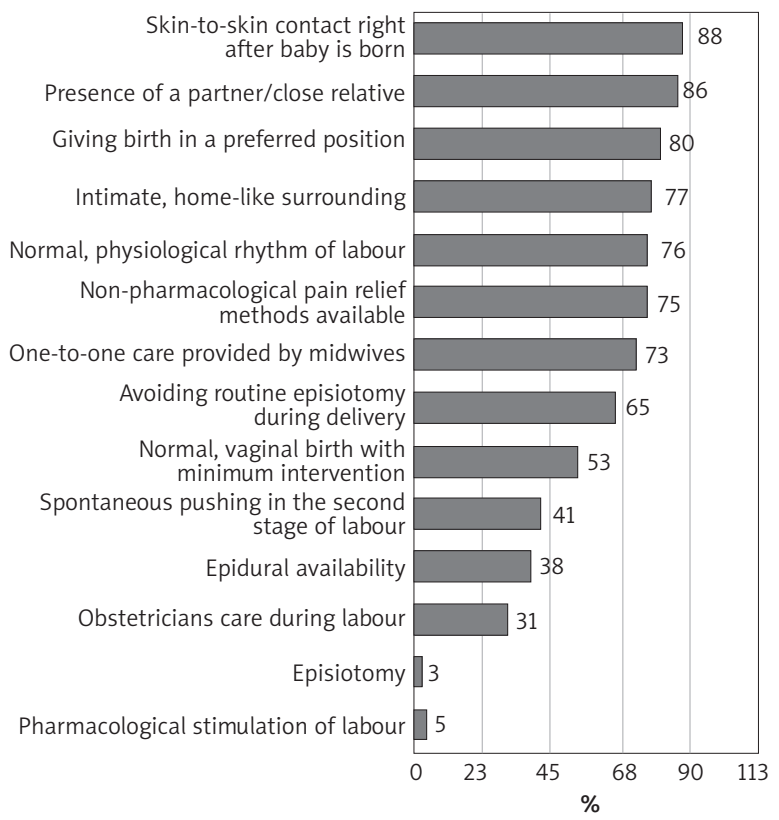

Figure 2. Aspects of care during childbirth important for respondents (more than one answer could be given in the question)

ment that a physiological birth in a birth center could be a safe alternative to hospital birth, while $37.9 \%$ of women $(n=58)$ partially agree with this statement. Very few women $(5.3 \%, n=8)$ disagreed with this statement (Table 2).

\section{Preferences about birth}

Aspects of care that women assessed as the most important were: "skin to skin" contact after childbirth (88\%), presence of partner/close relative (86\%), giving birth in a preferred position (80\%) (Figure 2).

All aspects which are the domains of midwife-led care in birth centers such as the use of non-pharmacological pain relief, one-to-one midwife care during delivery, intimate homelike surrounding were important for over $70 \%$ of respondents. For more than a half of women (53\%), minimizing intervention in the physiological process of labour and childbirth was essential.

We found a statistically significant $(p<0.001)$ association between variables: "Interest in giving birth in birth center" and "Physiological birth in the home is a safe alternative to giving birth in the hospital". From the group potentially interested in giving birthing birth center $41.2 \%$ of respondents fully agreed with the above sentence and $23.5 \%$ of the respondents from the same group agreed with the above statement partially (Figure 3).

Women who would like to give birth in birth center in $51.9 \%$ and $41.5 \%$, respectively totally and partially agreed that a physiological labour for a healthy woman normally is usually an uneventful experience. The relationship between the two variables was statistically significant ( $p=0.006$ ) (Table 3 ).

\section{Discussion}

A key indicator of the quality of care in perinatal period are clinical outcomes such as maternal wellbe- 
ing and the condition of the newborn. However, the assessment of women's birth experience should be an equally important indicator of the quality of care for those who are in charge [7, 8]. The implementation of new solutions to the existing care system is always a challenge, but mostly it is a step towards a higher quality of care. Although the current organization of maternity care in Poland aims at establishing natural childbirth for healthy women and babies centralization of perinatal care in large centers, which took place over the last two decades, brought about a visible increase in the medicalization [9]. A new model of care in birth centers is worth considering in order to reduce the level of medicalized births. It could also increase the quality of perinatal services. This model of is based on the perception of pregnancy and delivery as a physiological, normal life event. It also provides safe care due to the risk of possible complications at every stage of labour [10]. It should be noticed that reducing the frequency of unnecessary medical interventions used during delivery may reduce the percentage of cesarean sections in Poland. Cesarean section rate in Poland is one of the highest in Europe. In 2015 it reached $34.6 \%$ (according to OECD Health Statistics 2015) at the value recommended by the World Health Organization at the level of $15 \%[11,12]$. According to data from Childbirth with Dignity Foundation research in 2016 the rate of C-section was 43\% [13].

Aim of this paper was to recognize women opinion and perception of midwife-led model of care in birth centers. This model of care is not widespread in Poland, which probably led to a low level of knowledge among the respondents. The study showed that less than half $(44 \%)$ of women knew this form of care. However the characteristics of care in birth centers were recognized by the majority of participants. In the United Kingdom, where midwife-led model of care is much more popular $83 \%$ of women declared knowing alongside midwife-led units and 34\% freestanding midwife-led units [14].

According to personal preferences, as important features of perinatal care women mentioned giving birth with specialist care but also a low level of medicalization, including non-pharmacological methods of pain relief, one-to-one care. An important aspect of care was also intimate, homelike surrounding which was indi-

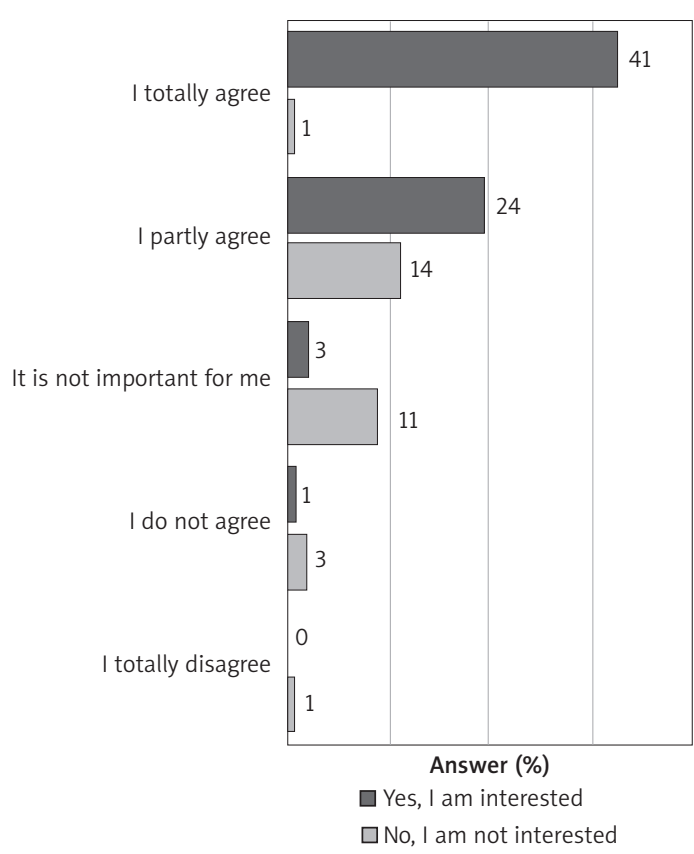

Figure 3. Comparison between women which are interested or not in giving birth in a birth center and their opinion on safety of giving birth in a birth center

cated by over $76 \%$ of respondents. Birth centers could be an example of the implementation of these aspects [15]. Macfarlane et al. comparing care in a London freestanding birth center and a hospital ward, analyzed the incidence of individual aspects of care depending on the place of delivery. This study indicates that women giving birth in birth center are subjected to fewer medical interventions. Women more often use non-pharmacological methods. They are also more likely to choose a comfortable position and to have the possibility of spontaneous pushing in the second stage of labour [16].

The study has several limitations. Firstly, the research tool used presents only selected aspects of care in birth centers and in hospital wards. It could reduce the respondents' response spectrum. Secondly, from the same reason it cannot be stated that the introduction of birth centers to health care in general would significantly improve the level of satisfaction among women. What is more, the research method could induce women who are interested in alternative meth-

Table 3. The relationship between being interested in giving birth in a birth center and opinion about physiological labour for a healthy woman

\begin{tabular}{|c|c|c|c|c|c|c|c|c|c|c|c|}
\hline \multirow{3}{*}{$\begin{array}{l}\text { Being interested } \\
\text { in giving birth } \\
\text { in a birth center } \\
\text { No }\end{array}$} & \multicolumn{11}{|c|}{ Physiological labour for a healthy woman normally is usually an uneventful experience } \\
\hline & \multicolumn{2}{|c|}{$\begin{array}{l}\text { I totally } \\
\text { agree }\end{array}$} & \multicolumn{2}{|c|}{$\begin{array}{l}\text { I partly } \\
\text { agree }\end{array}$} & \multicolumn{2}{|c|}{$\begin{array}{c}\text { It is not } \\
\text { important for me }\end{array}$} & \multicolumn{2}{|c|}{$\begin{array}{l}\text { I do not } \\
\text { agree }\end{array}$} & \multicolumn{2}{|c|}{$\begin{array}{l}\text { I totally } \\
\text { disagree }\end{array}$} & $P$-value* \\
\hline & 10 & $21.3 \%$ & 25 & $53.2 \%$ & 4 & $8.5 \%$ & 6 & $12.8 \%$ & 2 & $4.3 \%$ & \multirow{2}{*}{0.0003} \\
\hline Yes & 55 & $51.9 \%$ & 44 & $41.5 \%$ & 4 & $3.8 \%$ & 3 & $2.8 \%$ & 0 & $0.0 \%$ & \\
\hline
\end{tabular}

*Based on Fisher's exact test. 
ods of perinatal care to take part in the study. It could have influence on the final result of the study. A major strength of this research is its topic. It is almost not investigated at all in Poland. The results of work of midwives/obstetricians in birth centers are analyzed mainly in countries where this model of care is more developed. However, on the basis of numerous positive results of previous studies on this model $[3,12,15$, 17-21] an attempt to check whether this solution would be accepted in our country seems to be right. However it is necessary to conduct further, more extensive and complex research to inform policymaker on whether an expansion of this model of care is valuable. Summing up, it can be stated that the care that midwives provide in birth centers is an example of proper care during physiological pregnancy and labour. It allows to use the innate potential that every healthy woman has to give birth. In conclusion, it should be emphasized that if new solutions are valid they are worth implementing even if they affect a relatively small group of people.

\section{Conclusions}

This study offered some important insights in the preferences for alternative care provided in birth centers among women. Introducing birth centers in perinatal care for women in a physiological pregnancy with low risk of complications could better match their needs. Women show interest in birth center care during the perinatal period. The women opinion that giving birth without unnecessary medical interventions is important whether women choose consultant -led care or midwifery-led care. Respondents suggest that a physiological birth in a birth center is a safe alternative to giving birth in a hospital. The potential for new research triggered by these findings should be further explored.

\section{Conflict of interest}

The authors declare no conflict of interest.

\section{References}

1. WHO recommendations: intrapartum care for a positive childbirth experience. Geneva: World Health Organization 2018

2. Kirkham M. Birth Centres. A Social Model for Maternity Care. Elsevier, London 2003.

3. Better Births. Improving outcomes of maternity services in England. A Five Year Forward View for maternity care. National Maternity Review 2015; Available at: http:// www.england.nhs.uk/ourwork/futurenhs/mat-review

4. Dom Narodzin im. Świętej Rodziny w Łomiankach. Available at: http://www.dom-narodzin.pl

5. Przyszpitalny Dom Narodzin. Available at: http://szpital. szpitalzelazna.pl/poloznictwo/przyszpitalny-dom-narodzin

6. Hodnett ED, Downe S, Walsh D, Weston J. Alternative versus conventional institutional settings for birth. Cochrane Database Syst Rev 2010; 8: CD000012.

7. Iwanowicz-Palus GJ, Stadnicka G, Bień A. Organizacja opieki przedkoncepcyjnej i okołoporodowej determinantą zdrowia rodziny i społeczeństwa. Med Og Nauk Zdr 2013, 19: 313-318
8. The Royal College of Midwives (RCM). Standards for birth centres in England: a standards document. London 2008.

9. Junge I. Dom Narodzin - alternatywa dla szpitala. Konferencja „Poród jako doświadczenie kobiety - rola, misja, odpowiedzialność położnej i lekarza”. Fundacja Rodzić po Ludzku, Warszawa-Rynia 2005.

10. Stobnicka D, Iwanowicz-Palus G, Bień A. Alternatywne miejsca porodu. In: Alternatywne metody opieki okołoporodowej. Iwanowicz-Palus GI (ed). Wydawnictwo Lekarskie PZWL, Warsaw 2007; 103-105.

11. Opieka okołoporodowa na oddziałach położniczych. Informacja o wynikach kontroli. Najwyższa Izba Kontroli. Nr ewid. 203/2015/P/15/065/LB; Available at: https://www. nik.gov.pl/plik/id,11621,vp,13972.pdf.

12. OECD (2015), Health at a Glance 2015: OECD Indicators. OECD Publishing, Paris; doi: http://dx.doi.org/10.1787/ health_glance-2015-en.

13. Childbirth with Dignity Foundation 2017. Raport z monitoringu oddziałów położniczych. Medykalizacja porodu w Polsce. Warszawa, 2017; Available at: http://www. rodzicpoludzku.pl/images/rzecznictwo/RAPORT_Medykalizacja_porodu_w_Polsce_2017.pdf.

14. Redshaw M, Heikkila K. Delivered with care: a national survey of women's experience of maternity care 2010. University of Oxford, Oxford 2010.

15. Karlström A, Nested A, Hildingsson I. The meaning of a very positive birth experience: focus groups discussions with women. BMC Pregnancy and Childbirth 2015; 15: 251.

16. Macfarlane A, Rocca-Ihenacho L, Turner L. Survey of women's experiences of care in a new freestanding midwifery unit in an inner city area of London, England. Midwifery 2014; 30: 1009-1020.

17. Hollowell J, Rowe R, Townend J, Knight M, Li Y, Linsell L, Redshaw M, Brocklehurst P, Macfarlane A, Marlow N, McCourt C, Newburn M, Sandall J, Silverton L. The Birthplace in England national prospective cohort study: further analyses to enhance policy and service delivery decision-making for planned place of birth. Southampton (UK): NIHR Journals Library; 2015.

18. Begley C, Devane D, Clarke M, McCann C, Hughes P, Reilly M, Maguire R, Higgins S, Finan A, Gormally S, Doyle M. Comparison of midwife-led and consultant-led care of healthy women at low risk of childbirth complications in the Republic of Ireland: a randomised trial. BMC Pregnancy Childbirth 2011; 11: 85.

19. Gottvall K, Grunewald C, Waldenström U. Safety of birth centre care: perinatal mortality over a 10 -year period. BJOG 2004; 111: 71-8.

20. Overgaard C, Fenger-Grøn M, Sandall J. The impact of birthplace on women's birth experiences and perceptions of care. Soc Sci Med 2012; 74: 973-81.

21. Safer Childbirth. Minimum Standards for the Organization and Delivery of Care in Labour. Royal College of Obstetricians and Gynaecologists 2007; Available at: https:// www.rcog.org.uk/globalassets/documents/guidelines/ wprsaferchildbirthreport2007.pdf

\section{Address for correspondence:}

\section{Julia Nawrot}

Department of Rudiments of Midwifery Institute of Nursing and Midwifery

Faculty of Health Sciences

Jagiellonian University Medical College

ul. Zamojskiego 58, 30-519 Krakow, Poland

Phone: +48 501041443

E-mail: julia.nawrot@uj.edu.pl 